\title{
Examining the Relationship Between Enterprise Risk Management and Firm Performance in Malaysia
}

\author{
Mazurina Mohd Ali ${ }^{1}$, Nur Shazwani Ab Hamid ${ }^{1}$ \& Erlane K Ghani ${ }^{1}$ \\ ${ }^{1}$ Faculty of Accountancy, Universiti Teknologi MARA, Malaysia \\ Correspondence: Mazurina Mohd Ali, Faculty of Accountancy, Universiti Teknologi MARA, Malaysia.
}

Received: April 20, 2019

Accepted: May 7, 2019

Online Published: May 19, 2019

doi:10.5430/ijfr.v10n3p239

URL: https://doi.org/10.5430/ijfr.v10n3p239

\begin{abstract}
This study aims to examine the relationship between enterprise risk management (ERM) implementation and firm performance in Malaysia. Using the sample from 2010 to 2016, this study examines the relationship between ERM and firm performance among Malaysian top 100 public listed firms registered on the Index FTSE Bursa Malaysia 100 (FBM100) KLSE. This study also provides comparisons before and after the introduction of Bursa Malaysia Guidelines 2013. This study shows a positive and significant coefficient between profitability and firm performance towards ERM implementation. However, this study shows insignificant relationship between firm size, financial leverage and audit firm with firm performance. This study also shows that there is an increase in the mean score and standard deviation of these variables after the implementation of Bursa Malaysia Guideline 2013. The findings in this study provides an understanding to the Malaysian public listed firms on the importance of ERM and subsequently, maximise the benefits of ERM especially after the introduction of Bursa Malaysia Guidelines 2013 for the benefits of their stakeholders and regulatory improvement in future.
\end{abstract}

Keywords: enterprise risk management, firm performance, firm value, firm size, financial leverage, audit

\section{Introduction}

All firms would face a multiplicity of risks in strengthening their internal strategies and struggling for their external difficulties. In order to compete for resources and global market orientation, the firms need to have a durable competitive advantage and continuous demand for innovation (Oliva, 2016). The speed of innovation and changes in the global business environment has created great opportunities to the firm. It has provided critical challenge for the management to determine the type of risks the firm is facing and how much is the risk tolerance that their firms able to accept in order to create value and avoid highly complex of potential risks (Purnama, 2014; Chielotam, 2015; Mowlaei, 2017; Albasu and Nyameh, 2017; Beasley, Branson \& Hancock, 2017).

A common definition of risk is the likelihood of undesirable events or transactions that happen at a time that would adversely affect the achievement of objectives (Note 1). Meanwhile, risk management involves the process of identifying key risks, analyse the risks and establishing procedures to monitor the risk (Aven, 2016; Maroofi, Ardalan, and Tabarzadi, 2017; Kucukkocaoglu and Bozkurt, 2018; Maldonado-Guzman, Marin-Aguilar and Garcia-Vidales, 2018). The need for the risk management has increased since the global financial crisis of $2007-$ 2009. Many risk managers believed that the financial crisis was due to the failure in risk management (Note 2). Many companies have increased their key strategic risk information and prioritized risk management tasks. Enterprise risk management is known to be a more holistic approach as compared to traditional risk management in managing risk. It gives firms a greater awareness about the risks facing the organisation and the ability of the firm to respond effectively to the risk. This will lead to increase in efficiency and effectiveness of a firm's operations.

This study aims to examine the relationship between enterprise risk management implementation and firm performance in Malaysia. The findings in this study provide understanding to the Malaysian public listed firms and subsequently, maximise the benefits of ERM. The next section presents the literature review. This is followed by the research design and research framework in Section 3 and Section 4, respectively. Then, Section 5 presents the results and discussion. The last section, Section 6 presents the summary and conclusion. 


\section{Literature Review}

\subsection{Enterprise Risk Management}

Enterprise risk management (ERM) is a process that should be undertaken by management in order to identify and assess all type of risks that may affect firms' operation as well as firms' value. It applies a strategy to manage risk from an enterprise wide view in order to establish an effective risk management policy. The prime objective of risk management is to maximise shareholders' value (Lajili \& Zeghal, 2005; Santhi and Gurunathan, 2014; Anyanwu, et.al 2016; Jones and Mwakipsile, 2017; Mosbah, Serief, and Wahab, 2017; Malarvizhi, Nahar and Manzoor, 2018, Le, et.al. 2018). This can be achieved by improving capital efficiency through the provision of an objective basis for allocating corporate resources, by exposing areas of high risk and suggesting risk-based advances and by establishing a process which demonstrate to all stakeholders that the organization practices sound risk stewardship. According to the 1992 Cadbury Report, the board of directors are responsible to develop risk management policy in order to ensure that their firms make efforts to be aware of the major risks.

The first risk management standard was published by the Australian/New Zealand Standard (AS/NZS 4360: 1995). This standard represents multiple disciplines with updates in 1999 and 2004 and became the basis for The International Standards Organization (ISO). The Institute of Risk Management (IRM), a leading professional body for risk management had published guidelines for best practices in risk management, namely, ISO 31000: 2018 (previously known as ISO 31000:2009). The guidelines define ERM as a coordinated activity that directs and controls firms with regards to risk. The aim of ERM is to identify, assess and prepare for any dangers, hazards and other potentials disaster with both physical and figurative that may affect the operations and objectives of the firms. ERM expands the process to include all type of risks. It also involves making plan of actions available to all stakeholders, shareholders and potential investors, as part of their annual reports. ERM consists of eight interrelated components derived from the way the management runs the firm and are integrated with the management process. These components are: (i) internal environment; (ii) objective setting; (iii) event identification; (iv) risk assessment; (v) risk response; (vi) control activities; (vii) information and communication and (viii) monitoring.

\subsection{Enterprise Risk Management Implementation in Malaysia}

All firms are mandated to produce an annual report and are expected to provide useful information to users for better decision-making. Due to the changes in the business models, the traditional financial section alone is inadequate to meet the information needs of the stakeholders. Risk is an inevitable part of any businesses and became the concern of stakeholders. Thus, risks need to be disclosed sufficiently and well-timed. The significance of risk management disclosure is also a topic of concern among the regulators in Malaysia. By identifying risks and opportunities, the firms protect and create value for their stakeholders.

Amran, Rosli \& Hassan (2008) found that most of the risk disclosures were qualitative in nature and rigorously written in the chairman's statement. The total number of discussion on risk information provided by the Malaysian firms was much less. Ali and Taylor (2014) found that the most reported risk by Malaysian public listed companies was financial risk as it is mandated by the government. These finding indicated that risk disclosure reporting especially voluntary in nature by the Malaysian firms were still at the infancy stage and has urged the Malaysian government through various relevant parties to enhance firms' involvement in risk disclosure.

Kleffner, Lee \& McGannon (2003) provided several reasons for non-involvement in enterprise risk management (ERM) program. They are (i) lack of understanding in measuring the benefits and effectiveness of ERM implementation and (ii) the difficulties in measuring risks and correlations within the firm. Mustapha \& Adnan (2015) supported Kleefner et al.'s findings by stressing out that lacking in awareness and understanding of ERM concept by employees in the construction firms are the main factor that hinders the success of ERM implementation. Their results show that employees would be the first to experience and involve in such risks in their day-to-day operations. Ali, Norman, Ghani \& Haron (2019) also found that lack of knowledge and poor communication of risk management practices in construction industry lead to weak implementation of ERM. Therefore, commitment from the top management and participation from all level of employees are critical to certify a successful ERM implementation. Moreover, continuous monitoring and maintenance of risk management exercises are vital to effectively manage risks.

According to Togok, Isa \& Zainuddin (2016), ERM is indeed an integral part of an organization. Even though there are positive effects of ERM implementation towards firm performance, it is not widely practiced among the Malaysian firms due to no specific rule for mandatorily implementing ERM. In Malaysia, the only regulatory framework of risk management available is established in the Malaysian Code on Corporate Governance (MCCG). 
Hence, it is the firms' initiatives to adopt ERM. Consistent with the agency theory, shareholders require a more stringent monitoring on the management by increasing the level of engagement in ERM activities in order to enhance shareholders' protection.

Various reforms have been introduced as a way of providing the transparency, accountability and protection of shareholder's interest after the 1997 financial crisis in Malaysia. As a result, in January 2013, Bursa Malaysia issued the Statement on Risk Management and Internal Control (Guideline for Directors of Listed Issuers) (hereinafter referred to as RMIC 2013). The RMIC 2013 superseded the Statement on Internal Control (Guidance for Directors of Public Listed Firms) issued in 2000. The RMIC 2013 is voluntary. However, it encourages companies to disclose their risks and how those risks are managed. The RMIC 2013 was established to help improve governance practices. In due course, it is also to boost transparency among firms, stakeholders, regulators and the public at large.

Other standards/guidelines in relation with risk disclosure pertinent to the public listed companies in Malaysia include: (i) MFRS 7 (Financial Instruments: Disclosures); (ii) MFRS 9 (Financial Instruments); (iii) MFRS 132 (Financial Instruments: Presentation) and (iv) Guidelines with regard to risk management issued by Bank Negara Malaysia (BNM) which are made applicable only to financial institutions. The examples of the guidelines issued by BNM are "Risk Weighted Capital Adequacy Framework (RWCAF) - Disclosure Requirements (Pillar 3)" and "Guidelines on Financial Reporting for Banking Institutions". These guidelines and accounting standards emphasise on risks which are more quantifiable such as financial risks but not on other types of risks such operational risk and environmental risk (Ali and Taylor, 2014). Dissimilar from the guidelines issued by Bursa Malaysia which is voluntary in nature, all the MFRSs are mandatory. Non-compliance of these standards can lead to significant penalty by relevant governing bodies.

\subsection{Firm Performance and Enterprise Risk Management}

Performance of a firm may not only depend on the efficiency of the firm but also on the market. There are different financial measures that can be used to evaluate firm performance, namely, revenue, return on equity, return on assets, profit margin, sales growth, capital adequacy and stock prices. Another factor in considering evaluation of a firm performance is the relative value of the financial measures of the firm in relation to competitors within the same specific industry. This is because each industry is unique and making comparison across industries may provide bias understanding and interpretation about the firm performance.

A survey of risk managers in the United States (US) by Gates, Nicholas, and Walker (2012) provide support that enterprise risk management (ERM) improves firm performance and firm value. Gates et al.'s (2012) survey results indicated that ERM adoption improves management performance by reducing earnings volatility, increased profitability and risk-adjusted performance after ERM adoption. Other studies by Ping \& Muthuveloo (2015) also found that ERM implementation has significant influence on firm performance. On the other hand, Lin, Wen and Yu (2012) found that ERM implementation is negatively correlated with firm value measured by Tobin's Q and return on asset. This finding is consistent with Kommunuri, Narayan, Wheaton \& Jandug (2016) who explained that some firms in Vietnam found that ERM implementation has a negative impact on firm performance due to the difficulty for investors to explain the ERM value as they view it as a costly program.

\subsection{Factors Influencing Firm Performance Towards ERM Implementation}

\subsubsection{Firm Size}

The scope of risk occurs as firms become bigger and larger as size increases depending on the nature, timing and extent. By having an effective and efficient enterprise-wide risk management techniques, larger entities may have greater ability to implement ERM due to greater resources. Prior studies (e.g., Beasley et al., 2005 and Jabbour \& Abdel-Kader, 2015; Anigbogu and Nduka, 2014; Chang \& Liang, 2015) have also emphasised that firm size is an explanatory factor for the emergence and use of management control systems and is positively related to ERM adoption. Meanwhile, a study by Beretta and Bozzolan (2004) who examined firm size and industry in relation to risk disclosure showed no association between these two variables. On the other hand, a study by Linsley and Shrives (2006) who examined the relationship between firm size, level of risk and the extent of risk disclosure found a positive correlation between size and disclosure, however no correlation found between level of risk and risk disclosure. Falkner and Hiebl (2015) noted that risk management practices differ between large companies and small and medium enterprises (SMEs). This is basically due to fewer resources owned by SMEs. Likewise, these inadequate resources may limit the capacity and talent of smaller firms to address risks properly. Based on the argument that larger firm size is related to firm performance, this study hypothesizes the following:

H1: There is a positive and significant relationship between firm size and firm performance towards ERM 
implementation

\subsubsection{Financial Leverage}

Leverage is one of techniques in finance to use a borrowed fund in the purchase of an asset, with the expectation that the asset and the asset prices appreciation would exceed borrowing cost. An excessive amount of financial leverage increases the risk failure due to difficulty to repay debt. The more debt financing that a firm relied upon, the higher its financial leverage. Moreover, at a higher leverage level, lenders may possibly contend firms to develop ERM. Studies often used book value of liability divided by book value of equity as a proxy for leverage (e.g., Tahir \& Razali, 2011).

Previous studies revealed that firms having more growth opportunities and leverage and firms with poor variability performance in their profits tend to adopt ERM. Specifically, Liebenberg and Hoyt (2003) found that firms appointing chief risk officers (CROs) have greater financial leverage. Beasley et al. (2008) stated that market reacts positively to ERM adoption for large non-financial firms. A study by Khan, Hussain \& Mehmood (2016) suggested that firms implement ERM in order to improve their poor performance. Additionally, it is alleged that most firms use debt to finance their business which can be created by various options such as financial instruments. This will help firm to increase its value by reducing the cost of capital. Therefore, this study hypothesizes the following:

$\mathrm{H} 2$ : There is a positive and significant relationship between financial leverage and firm performance towards ERM implementation.

\subsubsection{Profitability}

Profitability can be measured using profitability ratios by utilizing profit margins, return on assets and return on equity. These ratios show the ability of the firm to generate earnings. According to Liebenberg and Hoyt (2003), a decrease in earnings volatility is classically stated as one of the many benefits of ERM. Eckles, Hoyt \& Miller (2014) provided a theoretical model of ERM that hypothesizes "greater risk reduction per dollar spent" for ERM-adopting firms. These firms have profit maximising incentives to reduce risk. They established their theoretical propositions, in which share price volatility reduced and operating profit per unit of risk is stronger as firms implemented ERM systems. A study by Pagach and Warr (2011) found that earnings volatility was highly significantly related to ERM adoption. This was a firm's effort to improve performance. This study suggests that profitability also influence firm performance. If a firm shows profit, it will attract potential investors and creditors will be more confident to lend money to the company. Therefore, this study hypothesizes the following:

H3: There is a positive and significant relationship between profitability and firm performance towards ERM implementation.

\subsubsection{Audit Firm}

Beasley et al. (2005) suggested that the type of auditors positively influence the phase of ERM implementation. They argued that firms are likely to adopt ERM framework if one of the big four auditors are the firm's external auditor. Besides, the higher the quality of accounting information, the more beneficial it should be in mitigating the default risk during a financial crisis. It is generally agreed that the size of audit firms is an appropriate indicator of audit quality. Golshan and Abdul Rasid (2012) found that firms with a big four auditors and higher financial leverage are more likely to have ERM framework.

This study suggests that big four audit firm also have an effect to firm performance. These audit firm are the four major player of accounting-related professional services networks in the world. Among their offers are audit and assurance services, taxation and management consulting, advisory and actuarial, corporate finance as well as legal services. These big fours hold huge majority of audit works not only for public firms but also for private firms. Yatim (2010) indicates that having one of the big four audit firms is also positively related with the establishment of a risk committee. Therefore, this study hypothesizes the following:

H4: There is a positive and significant relationship between large audit firm and firm performance towards ERM implementation.

\section{Research Method}

The target population of this study is the public listed firms on the main market on Bursa Malaysia. The study examines the annual reports of 100 public listed firms over a 7-year period from years 2010 until 2016 for each firm. The sampling frame is reduced to only firms with ERM processes and established board-level risk committees. This study excludes 11 firms in financial industry due to the different financial regulations. After exclusion of the financial industry, 89 public listed firms are used in this study to examine the relationship between ERM 
implementation, firm size, financial leverage, profitability and audit firm and firm performance in the public listed firms in Malaysia.

Figure 1 shows the industrial distribution of the sample based on the industrial classification benchmark (ICB). It shows that the trading services represent the highest sample coverage of $40 \%$. This is followed by the consumer products sector that covers $16 \%$ of the sample, industrial sector that covers $12 \%$, properties sector covers $8 \%$ and plantation sector covers 7\%. The REITS, IPC, construction and technology industries represent the lowest sample coverage.

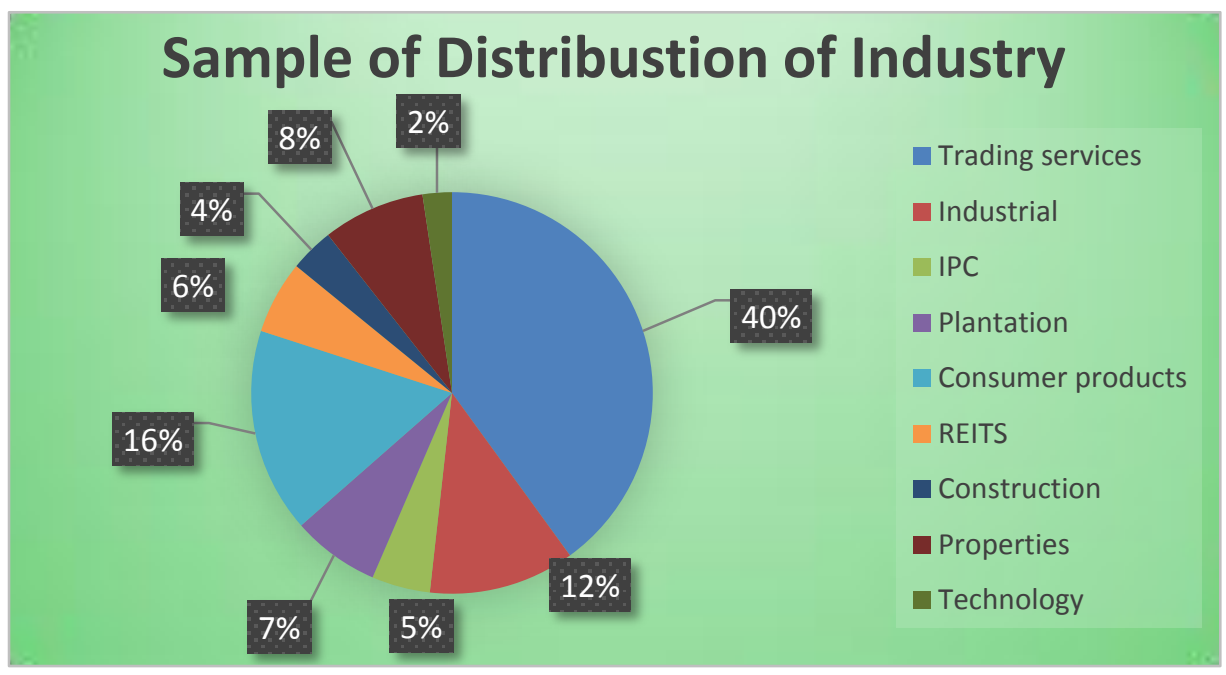

Figure 1. Sample of distribution of industry

The data for this study was collected from multiple sources. Most of the information needed for this study was gathered from companies' annual reports. These annual reports were downloaded from Bursa Malaysia website or from the company's website. Firms' information on firm performance was obtained from the Thomson DataStream database. The data collected involves total assets, total liabilities, market equity, return on assets and others. The annual reports and Thomson Reuters DataStream database were collected for the years 2010 until 2016. The data on availability of ERM process was collected from the sample firms' annual reports. The data to calculate firm performance was collected from the Thomson DataStream database.

\subsection{Variable Measurements}

\subsubsection{Dependent Variable}

\subsubsection{Firm Performance}

The dependent variable of this study is firm performance. The performance of a firm is critical to specify whether a firm is facing a profit or loss. Firm performance is the main concern of risk management. Management should give reasonable assurance that the firm has good internal control in order to increase the possibility of a firm's success and ultimately improve firm performance. This study uses Tobin's $Q$ as a measure of firm value because it has been widely used in the risk management research. According to Hoyt \& Liebenberg (2011), ERM is associated with significantly higher values of Tobin's Q, which is a measure of growth opportunities and firm value. This study measures Tobin's $Q$ ratio as the market value of equity plus book value of debt divided by book value of assets.

\subsubsection{Independent Variables}

\subsubsection{Enterprise Risk Management (ERM)}

This study attempts to identify ERM process for each of these firms as firms are not compulsory to report on their engagements in ERM. Thus, this study performs a detailed search of annual reports, websites and other media for evidence of ERM process such as Thomson and other search engines to perform separate keyword searches for each company. For example, the keyword searching for ERM processes are ERM, CRO, risk committee, enterprise-wide risk management, integrated risk management, corporate risk management, holistic risk management and strategic 
risk management in the annual reports. The sentences with the keywords were read to understand the ERM practices of the company. This method is consistent with previous studies (e.g., Ali and Taylor, 2014).

\subsubsection{Firm Size}

This study suggests that firm size also influence firm performance. As previous research suggests a relationship between firm size and performance, this study uses log of total assets as a proxy for firm size (Dang, Li \& Yang, 2018).

\subsubsection{Leverage}

This study suggests that leverage also influence firm performance. By referring to Leach \& Melicher (2012), this study uses total liabilities over market value of equity as a proxy for firm leverage.

\subsubsection{Profitability}

This study suggests that profitability also influence firm performance. Profitability can be derived from three most accepted financial ratios. First, by using profit margin i.e. net income divided by sales. Second, by using return on equity i.e. net income divided by total equity. Third, by return on assets i.e. net income divided by total assets. These ratios show how firms are able to generate revenue from the investment of assets. Based on previous research, this study controls for this effect by taking a log of return on assets as a proxy for profitability.

\subsubsection{Audit Firm}

This study suggests that big four audit firm also influence firm performance. This study also controls for this effect by using big four as a proxy for audit firm.

Table 1 below shows the operationalization of each variable.

Table 1. Operationalization of variables of the study

\begin{tabular}{|c|c|c|c|}
\hline Variable & Acronym & Measurement & Data Source \\
\hline Tobin's Q & $\mathrm{Q}$ & $\begin{array}{l}\text { Measures firm performance and calculated as log } \\
{[(\text { market value of equity }+ \text { book value of liability }) /} \\
\text { book value of assets }] \text {. }\end{array}$ & DataStream \\
\hline $\begin{array}{l}\text { Enterprise Risk } \\
\text { Management }\end{array}$ & ERM & $\begin{array}{l}\text { Dummy variable; } 1 \text { for presence of ERM, and } 0 \text { for } \\
\text { absence of ERM }\end{array}$ & Annual Report \\
\hline Firm Size & FSIZE & $\begin{array}{l}\text { Measures firm size and calculated as natural } \\
\text { logarithms of total assets }\end{array}$ & DataStream \\
\hline Leverage & LEV & $\begin{array}{l}\text { Measures firm leverage and calculated as natural } \\
\text { logarithms of total liabilities/ market value of } \\
\text { equity }\end{array}$ & DataStream \\
\hline Return on Assets & ROA & $\begin{array}{l}\text { Measures profitability and calculated as natural } \\
\text { logarithms of net income/total assets }\end{array}$ & DataStream \\
\hline Audit Firm & Big4 & $\begin{array}{l}\text { Dummy variable; } 1 \text { for firm audited by Big } 4 \text {, and } 0 \\
\text { for another audit firm }\end{array}$ & Annual Report \\
\hline
\end{tabular}

\subsection{Research Model}

This study used multiple regression analysis to test the relationship between the dependent variable, firm performance and the independent variables.

Therefore, regression model for this study is shown as follows:

$$
\text { Model: } \mathrm{Q}=\beta_{0}+\beta_{1} \mathrm{ERM}+\beta_{2} \mathrm{SIZE}+\beta_{3} \mathrm{LEV}+\beta_{4} \mathrm{ROA}+\beta_{5} \mathrm{BIG} 4+\varepsilon
$$

Where:

Q: Measures firm performance and calculated as log [(market value of equity + book value of liability)/ book value of assets] 
ERM: Dummy variable; 1 for firm-years beginning with first proof of ERM adoption and subsequent years, and 0 for firm-years before the ERM

SIZE: Measures firm size and calculated as natural logarithms of total assets

LEV : Measures firm leverage (total liabilities/ market value of equity)

ROA: Measures profitability (net income/total share outstanding)

Big4: Dummy variable; 1 for firm audited by Big4, and 0 for another audit firm

$\varepsilon$ : Error term

\section{Results}

\subsection{Descriptive Analysis}

Table 2 shows the effectiveness of firms in utilising their ERM processes with a mean score of 7.28 (SD=0.95). The mean score of ERM ranges from 1.01 to 1.10 (with minimum score 1 and maximum score 2) indicates that most firms have implemented ERM in their business operations. ERM score illustrates that most firms are monitoring their ERM program very effectively as described by COSO (2004).

Table 2. Descriptive statistic on ERM

\begin{tabular}{lllll}
\hline Year & Min & Max & Mean & SD \\
\hline 2016 & 1 & 2 & 1.01 & 0.106 \\
\hline 2015 & 1 & 2 & 1.01 & 0.106 \\
\hline 2014 & 1 & 2 & 1.01 & 0.106 \\
\hline 2013 & 1 & 2 & 1.01 & 0.106 \\
\hline 2012 & 1 & 2 & 1.06 & 0.232 \\
\hline 2011 & 1 & 2 & 1.08 & 0.303 \\
\hline 2010 & 1 & 2 & 1.10 & 0.950 \\
\hline Total & 7 & 14 & 7.2809 & \\
\hline
\end{tabular}

This study also found that all 89 of the Malaysian public listed firms have implemented ERM. Almost all firms have adopted ERM and the remaining firms largely are moving towards that trend. The result shows that many firms have considered ERM as important to their business operation. ERM integrates risks and adopts an enterprise-wide view of risk management for the whole organisation by considering people, processes, and scopes. O'Donnel (2005) explained that enterprise-wide risk management provides a more effective risk management since it offers a more holistic approach than the traditional risk management. This could reduce overall risk and increase the value of a company.

\subsection{Effect of ERM Before and After Implementation of RMIC 2013}

From the 89 sampled firms, not all firms existed throughout all the periods. For example, the KLCC Real Estate Investment Trust and IOI Properties Group Berhad were founded in 2013. This means that for the period before the implementation of RMIC 2013 Guideline, no data is available. Further, there was a company such as Lotte Chemical Titan Holding Berhad only change from 'Sendirian Berhad' to 'Berhad' in year 2017; thus, no data for period 2010 until 2016. This leads to the fact that not all 89 observations are considered.

Table 3 presents a comparison between two groups regarding the implementation of RMIC 2013's Guideline. Group 1 is between the period of years 2010 until 2012 (before implementation) and Group 2 is between the periods of years 2013 until 2016 (after implementation). Firm size is increasing after the implementation of RMIC 2013's Guideline. Mean and standard deviation after the implementation have increasing as compared to before the implementation with a mean score is $35.83(\mathrm{SD}=6.19)$ and 25.78 ( $\mathrm{SD}=4.84)$ respectively. According to COSO framework (2004), firm size is one of the characteristics that influence whether the framework is implemented efficiently and effectively. By having an effective and efficient guideline, larger entities which have greater resources may have greater ability to implement ERM. 
Table 3. Descriptive statistics between before and after RMIC 2013 guideline

\begin{tabular}{lllll}
\hline & \multicolumn{2}{l}{ Before RMIC 2013's Guideline } & \multicolumn{2}{l}{ After RMIC 2013's Guideline } \\
\hline Variables & Mean & SD & Mean & SD \\
\hline TOBINQ & 2.6603 & 2.0884 & 3.9538 & 3.1333 \\
\hline ERM & 3.2360 & 0.7541 & 4.0449 & 0.4240 \\
\hline SIZE & 25.7782 & 4.8353 & 35.8310 & 6.1934 \\
\hline LEV & 1.9825 & 2.0710 & 2.3562 & 2.3738 \\
\hline ROA & 0.2274 & 0.2234 & 0.6154 & 1.8444 \\
\hline AUD & 3.7528 & 1.6602 & 4.5955 & 1.4749 \\
\hline
\end{tabular}

Notes: BM is Bursa Malaysia

Leverage is also increasing between the two different periods, with also an increasing mean score and standard deviation before and after the implementation of Bursa Malaysia 2013's Guidelines with a mean score 1.98 $(\mathrm{SD}=2.07)$ and $2.36(\mathrm{SD}=2.37)$ respectively. This indicates that leverages are increasing between the two different periods, which was also indicates that firms appear to be implementing ERM when they are more volatile, have greater earnings volatility and greater leverage.

Next, return on assets is increasing after the implementation of RMIC 2013's Guideline, as was expected. It also shows that the mean score after the implementation is much larger than before the implementation with a mean score $0.62(\mathrm{SD}=1.84)$ and $0.23(\mathrm{SD}=0.22)$ respectively. This indicates that most firms have good performance after the implementation of Bursa Malaysia 2013's Guideline.

Furthermore, Table 3 shows that firm performance is increasing after the implementation of RMIC 2013's Guideline. The mean score and standard deviation before and after the implementation of the guideline are $2.66(\mathrm{SD}=2.09)$ and 3.95 (SD=3.13), respectively. Nicholas and Walker (2012) discovered that ERM implementation improves firm performance and firm value. From the result, it shows that with the guidelines, the firm performances are better than before the implementation of the guideline. Gates et al.'s (2012) also indicate that ERM implementation improves management performance regarding reduced earnings volatility, increased profitability, ability to meet strategic goals, and risk-adjusted performance after ERM implementation. The ERM implementations show an increase between the two periods i.e., higher mean. The increase of the ERM indicates that firms are further implementing ERM after the RMIC 2013's Guideline. This could indicate that some firms see the importance of risk management and started to implement it.

\subsection{Inferential Analysis}

\subsubsection{Tolerance and Variance Inflation Factor (VIF) Values}

Table 4 is prepared for the purpose of examining the presence of multicollinearity through the tolerance and variance inflation factor (VIF) among variables. The very low value for the tolerance such as near to zero shows the possibility of multicollinearity (Hair et al., 2010). As shown in the Table 4, the tolerance column shows none of the variables are near to zero which indicates the absence of multicollinearity problem. In addition, all VIF values in the table are lower than 10 .

Table 4. Tolerance and Variance Inflation Factor (VIF)

\begin{tabular}{lll}
\hline \multirow{2}{*}{ Variables } & Collinearity Statistics \\
\cline { 2 - 3 } & Tolerance & VIF \\
\hline ERM & 0.514 & 1.946 \\
\hline SIZE & 0.557 & 1.794 \\
\hline LEV & 0.605 & 1.652 \\
\hline ROA & 0.852 & 1.174 \\
\hline AUD & 0.515 & 1.944 \\
\hline
\end{tabular}




\subsubsection{Correlation Analysis}

Table 5 shows that in the correlation matrices, all the variables are correlated to each other, including ERM. The correlations show whether the variables are related to each other, which is the first step in determining whether ERM implementation affects firm performance.

Table 5. Pearson correlation among independent, dependent and control variable

\begin{tabular}{lllllll}
\hline & TOBINQ & ERM & SIZE & LEV & ROA & AUD \\
\hline TOBINQ & 1 & & & & & \\
\hline ERM & -0.083 & 1 & & & & \\
\hline SIZE & $-0.408^{* *}$ & 0.090 & 1 & & & \\
\hline LEV & $-0.384^{* *}$ & 0.032 & $0.620^{* *}$ & 1 & & \\
\hline ROA & $0.535^{* *}$ & -0.129 & $-0.373^{* *}$ & $-0.233^{*}$ & 1 & \\
\hline AUD & -0.003 & $0.690^{* *}$ & 0.034 & -0.066 & -0.077 & 1 \\
\hline
\end{tabular}

* Correlation is significant at the 0.05 level (1-tailed)

** Correlation is significant at the 0.01 level (2-tailed)

Table 5 shows that ERM have negative coefficient with the performance measures (TOBINQ), and these are insignificant. The coefficient is closer to 0 ; this indicates that there is no correlation between these variables. The result suggests that even though the firms are performing well, it does not necessary that firms adopt ERM. ERM shows significant correlations with independent variables, namely, audit firm (AUD). Furthermore, the coefficients are also positive, which provides a further indication that audit firm is enhancing the implementation of ERM. Further, ERM shows negative coefficient with return on asset (ROA) but not significant. For other independent variables coefficients are closer to 0 . This indicates that there is no correlation between these variables. Table 5 shows that return on assets (ROA) is significantly positively correlate with firm performance (TOBINQ). This indicates that profitability increases the firm performance or adds value to firm. Meanwhile, other independent variables such as size (SIZE) and leverage (LEV) show negative correlation with firm performance. This could indicate that leverage leads to lower performance, or higher performance leads to lower leverage. The correlation between audit firm (AUD) and firm performance is small and insignificant. The independent variables also show some correlations with each other, namely, size with leverage, size with return on asset and leverage with return on asset.

\subsubsection{Multiple Regression Analysis}

Table 6 represents the multiple regression analysis for this study. The results show that firm performance is significant at $1 \%$ level $(\mathrm{F}=6.00)$. The table also shows that the adjusted $\mathrm{R}^{2}$ of 0.366 indicates that $36.6 \%$ variance of firm performance (dependent variable) was explained by the variance of enterprise risk management (ERM), size (SIZE), leverage (LEV), return on asset (ROA) and audit firm (AUD) as independent variables.

Table 6. Regression Statistic of Enterprise Risk Management (ERM) on firm performance (TOBINQ) and independent variables (SIZE, LEV, ROA, AUD)

\begin{tabular}{llll}
\hline Independent Variables & Beta & Std. Error & t \\
\hline Constant & 9.839 & 6.042 & 1.682 \\
\hline ERM & -0.230 & 0.795 & -0.289 \\
\hline SIZE & -0.053 & 0.069 & -0.758 \\
\hline LEV & -0.236 & 0.163 & -1.452 \\
\hline ROA & 3.017 & 0.814 & $3.708^{* *}$ \\
\hline AUD & 0.094 & 0.280 & 0.337
\end{tabular}




\begin{tabular}{llll}
\hline R-squared & 0.366 & F-Statistic & 6.001 \\
\hline Adjusted R-squared & 0.305 & Prob (F-statistic) & 0.000 \\
\hline Durbin-Watson stat. & 1.924 & & \\
\cline { 2 - 2 }
\end{tabular}

** Correlation is significant at the 0.01 level (2-tailed)

Table 6 shows that there is negative relationship between ERM and firm performance and insignificant $(\beta=-0.29$; $\mathrm{p}>.01)$. The result in Table 6 does not support the hypothesis that firms with ERM practice would have a higher performance (TOBINQ) than firms which are not. Therefore, H1 is rejected. This result suggests that the practice of ERM in Malaysia does not influence firm performance. This result is consistent with previous studies such as Tahir \& Razali (2011) and McShane (2018). Table 6 shows a negative and insignificant relationship between size and firm performance $(\beta=-76 ; p>.01)$. This result does not support the hypothesis that bigger firm size which practice ERM would have a higher firm performance than smaller firms. It also suggested that firm size does not influence firm performance to explain the extent of ERM implementation. Thus, $\mathrm{H} 2$ is rejected.

Next, the result shows that there is negative and not significant relationship between financial leverage (LEV) and firm performance $(\beta=-1.45 ; p>.01)$. The result in Table 6 does not support the hypothesis that higher leverage which practice ERM would have a higher firm performance than lower financial leverage. It also suggested that financial leverage does not influence firm performance to explain the extent of ERM implementation. Thus, H3 is rejected. This result may imply that excessive leverage can increase the probability of financial distress.

Furthermore, Table 6 shows that there is positive and significant relationship between return on asset (ROA) and firm performance $(\beta=3.71 ; p<.01)$. This result supports the hypothesis that profitability has positive and significant relationship with firm performance. It also suggested that the profitability could influence firm performance toward the ERM implementation. This result is consistent with prior studies by Hoyt and Lienbenberg (2011) and Tahir and Razali (2011). Thus, H4 is supported.

Lastly, Table 6 shows a positive but not significant relationship between audit firm and firm performance $(\beta=-0.34$; $\mathrm{p}<.01$ ). According to Talley (2006), if the firm's auditor is one of the big four, the firm is more likely to have adopted a more-developed framework of ERM. Furthermore, they assume that engaging one of the big fours as a firm's auditor is positively related to ERM framework adoption (Golshan \& Abdul Rasid, 2012). Although the direction is positive but it is not significant. Thus, H5 is rejected.

\section{Conclusions}

ERM is a vital part of corporate strategy which forms part of the most important business processes and corporate culture (Fraser and Simkins, 2010). This study has shed some lights on the firm performance among public listed firms on the main market of Bursa Malaysia towards ERM implementation. The findings of this study serve as a platform for academics, researchers and other interested parties to further understand the way public listed firms manage their activities and financial records. Accordingly, this study could open-up others in seeing the importance of ERM implementation in Malaysia, and not only view them as one of the sections that does not bring any profit other than providing services to the community. This is because, nowadays, majority of the firms have implemented ERM in their business operation. Overall, the findings of this study could be used as a guide in developing the appropriate framework and best practices that can be used to improve and add value to the firms.

This study is not without its limitations. One main limitation is the inability to identify the point in time when the firms implemented ERM and thus, cannot perform a before-and-after comparison. However, to the extent that this study can distinguish between firms that engage in ERM and those that do not, this study can provide some evidences on the relation between ERM and firm performance.

Finally, to make the research more robust, future study can use other variables that can potentially improve firm performance of public listed firms and other measurement to measure the firm performance instead of Tobin's Q.

\section{References}

Albasu, J., \& Nyameh, J. (2017). Relevance of Stakeholders Theory, Organizational Identity Theory and Social Exchange Theory to Corporate Social Responsibility and Employees Performance in the Commercial Banks in Nigeria. International Journal of Business, Economics and Management, 4(5), 95-105. https://doi.org/10.18488/journal.62.2017.45.95.105

Ali, M. M., \& Taylor, D. (2014). Content analysis of corporate risk disclosure in Malaysia. Proceedings of 4th 
Annual International Conference on Accounting and Finance (AF2014).

Ali, M. M., Norman, S. Z., Ghani, E. K., \& Haron, N. H. (2019). The influence of risk management on construction project performance: A case study. The Journal of Social Sciences Research, Special Issue, (1), 69-75. https://doi.org/10.32861/jssr.spi1.69.75

Amran, A., Rosli, A. M., \& Hassan, M. C. H. (2008). Risk reporting: An exploratory study on risk management disclosure in Malaysian annual reports. Managerial Auditing Journal, 24(1), 39-57. https://doi.org/10.1108/02686900910919893

Anigbogu, U. E., \& Nduka, E. K. (2014). Stock market performance and economic growth: Evidence from Nigeria employing vector error correction model framework. The Economics and Finance Letters, 1(9), 90-103. https://doi.org/10.18488/journal.29/2014.1.9/29.4.90.103

Anyanwu, J. O., Okoroji, L. I., Ezewoko, O. F., \& Nwaobilor, C. A. (2016). The Impact of Training and Development on Workers Performance in Imo State. Global Journal of Social Sciences Studies, 2(2), 51-71.

Aven, T. (2016). Risk assessment and risk management: Review of recent advances on their foundation. European Journal of Operational Research, 253(1), 1-13. https://doi.org/10.1016/j.ejor.2015.12.023

Beasley, M. S., Branson, B., \& Hancock, B. (2017). The State of Risk Oversight: An Overview of Enterprise Risk Management Processes.

Beasley, M. S., Clune, R., \& Hermanson, F. R. (2005). Enterprise risk management: An empirical analysis of factors associated with the extent of implementation. Journal of Accounting and Public Policy, 24, 521-531. https://doi.org/10.1016/j.jaccpubpol.2005.10.001

Beasley, M. S., Pagach, D. P., \& Warr, R. S. (2008). Information conveyed in hiring announcementsof senior executives overseeing enterprise-wide risk management processes. Journal ofAccounting, Auditing, \& Finance, 23, 311-332. https://doi.org/10.1177/0148558X0802300303

Beretta, S., \& Bozzolan, S. (2004). A framework for the analysis of firm risk communication. The International Journal of Accounting, 39(3), 265-288. https://doi.org/10.1016/j.intacc.2004.06.006

Bursa Malaysia. (2013). Statement on Risk Management \& Internal Control (Guidelines for Directors of Listed Issuers). Kuala Lumpur: Bursa Malaysia.

Chang, W. S., \& Liang, C. (2015). Exploring potential entrants' perceptions of the performance of an agrirural social enterprise in Taiwan. International Journal of Management and Sustainability, 4(10), 205-217. https://doi.org/10.18488/journal.11/2015.4.10/11.10.205.217

Chielotam, A. N. (2015). Oguamalam Masquerade Performance beyond Aesthetics. Humanities and Social Sciences Letters, 3(2), 63-71. https://doi.org/10.18488/journal.73/2015.3.2/73.2.63.71

Chima, P., \& Kasim, U. (2018). Public-private partnership as a strategy for e-governance funding in Africa: The gains and the pains. International Journal of Public Policy and Administration Research, 5(2), 37-47. https://doi.org/10.18488/journal.74.2018.52.37.47

Committee of Sponsoring Organizations of the Treadway Commission (COSO). (2004). Enterprise Risk Management -Integrated Framework.

Dang, C., Li, Z., \& Yang, C. (2018). Measuring firm size in empirical corporate finance. Journal of Banking \& Finance, 86, 159-176. https://doi.org/10.1016/j.jbankfin.2017.09.006

Eckles, D. L., Hoyt, R. E., \& Miller, S. M. (2014). The Impact of Enterprise Risk Management on the Marginal Cost of Reducing Risk: Evidence From the Insurance Industry. Journal of Banking \& Finance, 43(1). https://doi.org/10.1016/j.jbankfin.2014.02.007

Falkner, E. M., \& Hiebl, M. R. W. (2015). Risk management in SMEs: a systematic review of available evidence. The Journal of Risk Finance, 16(2), 122-144. https://doi.org/10.1108/JRF-06-2014-0079

Gates, S., Nicolas, J.-L., \& Walker, P. L. (2012). Enterprise risk management: A process for enhanced management and improved performance. Management Accounting Quarterly, 13(3), 28-38.

Golshan, N. M., \& Abdul Rasid, S. Z. (2012). What Leads Firms to Enterprise Risk Management Adoption? A Literature Review. Paper presented at the International Conference on Economics, Business and Marketing Management, Singapore. 
Hair, J. F. Jr., Black, W. C., Babin, B. J., \& Anderson, R. E. (2010). Multivariate data analysis. Upper Saddle River. New Jersey: Pearson Prentice Hall.

ISO 31000. (2018). A Risk Practitioners Guide to ISO 31000: 2018. Institute of Risk Management. Retrieved 14 March 2019, from https://www.theirm.org/media/3513119/IRM-Report-ISO-31000-2018-v3.pdf

Jabbour, M., \& Abdel-Kader, M. (2015). Changes in capital allocation practices - ERM and organisational change. Accounting Forum, 39, 295-311. https://doi.org/10.1016/j.accfor.2015.08.001

Jones Osasuyi, O., \& Mwakipsile, G. (2017). Working Capital Management and Managerial Performance in some Selected Manufacturing Firms in Edo State Nigeria. Journal of Accounting, Business and Finance Research, l(1), 46-55. https://doi.org/10.20448/2002.11.46.55

Khan, M. J., Hussain, D., \& Mehmood, W. (2016). Why do firms adopt enterprise risk management (ERM)? Empirical evidence from France. Management Decision, 54(8), 1886-1907. https://doi.org/10.1108/MD-09-2015-0400

Kleffner, A., Lee, R., \& McGannon, B. (2003). The effect of corporate governance on the use of Enterprise Risk Management: Evidence from Canada. Risk Management and Insurance Review, 6(1), 53-73. https://doi.org/10.1111/1098-1616.00020

Kommunuri, J., Narayan, A., Wheaton, M., \& Jandug, L. (2016). Enterprise Risk Management and Firm Performance Empirical evidence from Vietnam. New Zealand Journal of Applied Business Research, 14(2), 17-28.

Kucukkocaoglu, G., \& Bozkurt, M. A. (2018). Identifying the Effects of Mergers and Acquisitions on Turkish Banks Performances. Asian Economic and Financial Review, 6(3), 235-244. https://doi.org/10.18488/journal.8.2018.63.235.244

Lajili, K., \& Zeghal, D. (2005). A Content Analysis of Risk Management Disclosures in Canadian Annual Reports. $\begin{array}{lllll}\text { Canadian Journal of Administrative } & \text { Sciences, } & 22(2), & 125-142 .\end{array}$ https://doi.org/10.1111/j.1936-4490.2005.tb00714.x

Le, H. L., Vu, K. T., Du, N. K., \& Tran, M. D. (2018). Impact of Working Capital Management on Financial Performance: The case of Vietnam. International Journal of Applied Economics, Finance and Accounting, 3(1), 15-20. https://doi.org/10.33094/8.2017.2018.31.15.20

Leach and Melicher. (2012). Entrepreneurial Finance (4th ed.). South-Western publications, USA.

Liebenberg, A. P., \& Hoyt, R. E. (2003). The Determinants of Enterprise Risk Management: Evidence From the Appointment of Chief Risk Officers. Risk Management and Insurance Review, 6(1). https://doi.org/10.1111/1098-1616.00019

Lin, Y., Wen, M. M., \& Yu, J. (2012). Enterprise risk management: Strategic antecedents, risk integration, and performance. North American Actuarial Journal, 16(1), 1-28. https://doi.org/10.1080/10920277.2012.10590630

Linsley, P. M., \& Shrives, P. J. (2006). Risk reporting: A study of risk disclosures in the annual reports of UK companies. The British Accounting Review, 38, 387-404. https://doi.org/10.1016/j.bar.2006.05.002

Malarvizhi, C. A., Nahar, R., \& Manzoor, S. R. (2018). The Strategic Performance of Bangladeshi Private Commercial Banks on Post Implementation Relationship Marketing. International Journal of Emerging Trends in Social Sciences, 2(1), 28-33. https://doi.org/10.20448/2001.21.28.33

Maldonado-Guzman, G., Marin-Aguilar, J., \& Garcia-Vidales, M. (2018). Innovation and Performance in Latin-American Small Family Firms. Asian Economic and Financial Review, 8(7), 1008-1020. https://doi.org/10.18488/journal.aefr.2018.87.986.998

Maroofi, F., Ardalan, A. G., \& Tabarzadi, J. (2017). The Effect of Sales Strategies in the Financial Performance of Insurance Companies. International Journal of Asian Social Science, 7(2), 150-160. https://doi.org/10.18488/journal.1/2017.7.2/1.2.150.160

McShane, M. (2018). Enterprise risk management: history and a design science proposal. The Journal of Risk Finance, 19(2), 137-153. https://doi.org/10.1108/JRF-03-2017-0048

Mosbah, A., Serief, S. R., \& Wahab, K. A. (2017). Performance of Family Business in Malaysia. International Journal of Social Sciences Perspectives, 1(1), 20-26. https://doi.org/10.33094/7.2017.11.20.26

Mowlaei, M. (2017). The Impact of AFT on Export Performance of Selected Asian Developing Countries. Asian 
Development Policy Review, 5(4), 253-261. https://doi.org/10.18488/journal.107.2017.54.253.261

Mustapha, M., \& Adnan, A. (2015). A Case Study of Enterprise Risk Management Implementation in Malaysian Construction Firms. International Journal of Economics and Financial Issues, (5), 70-76.

O’Donnell, E. (2005). Enterprise risk management: A systems-thinking framework for the event identification phase. International Journal of Accounting Information Systems, 6(3), 177-195. https://doi.org/10.1016/j.accinf.2005.05.002

Oliva, F. L. (2016). A maturity model for enterprise risk management. International Journal of Production Economics, 173, 66-79. https://doi.org/10.1016/j.ijpe.2015.12.007

Pagach, D., \& Warr, R. (2007). An Empirical Investigation of the Characteristics of Firms Adopting Enterprise Risk Management. College of Management, North Carolina State University.

Ping, T. A., \& Muthuveloo, R. (2015). The Impact of Enterprise Risk Management on Firm Performance: Evidence from Malaysia. Asian Social Science, 11(22), 149-159. https://doi.org/10.5539/ass.v11n22p149

Purnama, C. (2014). Improved Performance Through Empowerment of Small Industry. Journal of Social Economics Research, 1(4), 72-86.

Santhi, N. S., \& Gurunathan, K. B. (2014). Fama-French Three Factors Model in Indian Mutual Fund Market. Asian Journal of Economics and Empirical Research, 1(1), 1-5.

Tahir, I. M., \& Razali, A. R. (2011). The Relationship Between Enterprise Risk Management (Erm) And Firm Value: Evidence From Malaysian Public Listed Firms. International Journal of Economics and Management Sciences, $1(2), 32-41$.

Togok, S. H., Isa, C. R., \& Zainuddin, S. (2016). Enterprise Risk Management Adoption in Malaysia: A Disclosure Approach. Asian Journal of Business and Accounting, 9(1), 83-104.

Yatim, P. (2010). Board structures and the establishment of a risk management committee by Malaysian listed firms. Journal of Management \& Governance, 14, 17-36. https://doi.org/10.1007/s10997-009-9089-6

Yazid, A. S., Husin, M. R., \& Wand Daud, W. N. (2011). An Examination of Enterprise Risk Management (ERM) Practices among the Government-Linked Firms (GLCs) in Malaysia. International Business Research, 4(4), 94-103. https://doi.org/10.5539/ibr.v4n4p94

\section{Notes}

Note 1. Retrieved from https://erm.ncsu.edu/library/article/coso-erm-framework

Note $2 . \quad$ Retrieved from https://www.businessinsurance.com/article/20090614/story/906099984/poor-risk-management-seen-as-a-cause-of-cri sis 